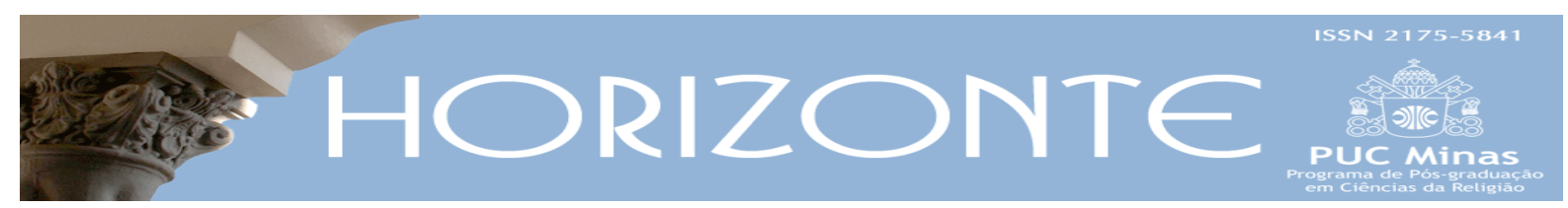

Dossiê: Religião e Demografia - Editorial DOI - 10.5752/P.2175-5841.2014v12n36p1051

\title{
O Brasil e as fontes de dados demográficos sobre religião
}

The Brazil and demographic data sources on religion

René Decol*

Em termos de fontes de dados estatísticos sobre religião, o Brasil ocupa no mundo uma posição singular: é um dos poucos países em que o censo demográfico oficial inclui uma pergunta sobre religião. Na maior parte dos países vigora um arraigado antagonismo contra a inclusão de um quesito deste tipo em pesquisas feitas pelo governo. Esse antagonismo baseia-se na convicção de que a religião é um assunto íntimo e privado de cada indivíduo. Alega-se que uma pergunta deste tipo viola o princípio da liberdade de consciência, ou ainda que as informações referentes às minorias religiosas possam ser interpretadas sob luz negativa ou preconceituosa.

Esse antagonismo é maior nos países da Europa marcados por séculos de disputas religiosas. França, Bélgica, Espanha, Portugal e Itália, por exemplo, não trazem a pergunta no censo. Nos Estados Unidos, por sua vez, o censo também não pergunta sobre religião por injunção da suprema corte. Nesses países as estatísticas sobre religião são geralmente produzidas por institutos privados de pesquisa de opinião. Embora muitos deles sejam bastante rigorosos do ponto de vista metodológico, não são levantamentos sistemáticos; só os censos, com a sua regularidade, permite que se estabeleça um panorama capaz de retratar a evolução da dimensão religiosa em uma sociedade ao longo do tempo. Talvez pela inexistência de uma "questão religiosa" na história brasileira, a presença de uma pergunta sobre religião no levantamento populacional mais amplo e importante do país nunca chegou a ser um problema.

O objetivo de incluir uma pergunta sobre religião nos censos é enumerar os membros de cada grupo. A questão aparece na forma de um item separado no questionário da amostra e é dirigida a cada indivíduo, ao qual pede-se que declare sua religião com suas próprias palavras, não importando se frequenta uma igreja ou

* Sociólogo e doutor em Demografia pela Unicamp. País de origem: Brasil. E-mail: rdecol@gmail.com 
templo, ou se observa todos os seus preceitos. A resposta é opcional, ao contrário das demais, cuja obrigatoriedade se assenta em algum dispositivo constitucional.

A simples evolução das categorias enumeradas ao longo do tempo já nos diz algo importante sobre a sociedade brasileira. Nosso primeiro censo, o "Recenseamento do Brazil em 1872", como foi oficialmente chamado, tinha na variável religião apenas duas categorias: “catholicos e acatholicos”. Se alguém na elite do Segundo Império estivesse preocupado com a eventual chegada de muçulmanos entre os escravos, e protestantes entre os imigrantes vindos do norte da Europa, a preocupação desapareceu quando os resultados foram publicados: apenas 20 mil entre os quase dez milhões de brasileiros de então se disseram "acatholicos".

$\mathrm{Na}$ maior parte das vezes a pergunta era aberta, e os resultados finais enumeravam as categorias religiosas que apareciam com mais frequência durante a tabulação final. Para todos os efeitos a história dos censos de qualidade começa em 1940, quando foi criado o IBGE. Não tivemos um censo em 1930 e o censo de 1920 foi o único a não incluir uma pergunta sobre religião. Portanto, quando o censo de 1940 foi realizado, um marco na história das estatísticas sociais, havia um lapso enorme na informação sobre as religiões no Brasil. Quais novas religiões teriam aparecido, trazidas por imigrantes e pelas transformações que o país passara nas primeiras quatro décadas do século 20? Uma vez realizado o censo, as categorias enumeradas foram as seguintes: católicos, protestantes, espíritas, positivistas, ortodoxos, maometanos, budistas, xintoístas, judeus e sem religião. A presença de "positivistas" entre as denominações religiosas atesta a importância do positivismo durante a Era Vargas.

As categorias se mantiveram basicamente as mesmas nos censos de 1950 e 1960. A única modificação diz respeito a agregação dos números das minorias, cujo eventual tamanho não justificasse a manutenção de uma enumeração em separado. $O$ censo de 1950 foi de ótima qualidade, mas como ainda não havia sido informatizado, o que só aconteceria em 1970, os dados estão limitados àqueles que foram publicados nos volumes impressos pelo IBGE. Já o censo de 1960 foi bastante tumultuado e seus dados não podem ser utilizados sem que se faça uma série de restrições sobre a sua precisão. 
Em 1970 a pergunta sobre religião foi mantida, mas como este censo foi processado por computador (pela primeira vez na história dos censos brasileiros), e como a memória dos computadores era então limitada, a questão apareceu na forma fechada, previstas apenas seis categorias: católicos, evangélicos, espíritas, outros, sem religião e sem declaração.

No censo de 1980, a pergunta voltou a ser aberta, ou seja, as categorias voltaram a ser estabelecidas apenas na fase da tabulação. Nove categorias foram enumeradas: católica, protestante tradicional, protestante pentecostal, espírita kardecista, espírita afro-brasileira, oriental, judaica, outras e sem religião. Note-se que a própria estruturação das categorias que agora incluem "protestante tradicional" e "protestante pentecostal” já manifesta por si só a importância do crescimento dos evangélicos.

Especialmente a partir da redemocratização o IBGE passou a ouvir cada vez mais a sociedade civil na formulação de suas pesquisas, especialmente no que diz respeito às pesquisas de natureza demográfica, o que se explica, em parte pela existência de uma comunidade acadêmica formada por núcleos de demografia muito bem estruturados em algumas das principais universidades do país. Atendendo sugestões de pesquisadores acadêmicos e de organizações não governamentais, o censo de 1991 inicia uma fase em que procura-se ampliar ao máximo o espectro dos grupos religiosos tabulados nos resultados finais.

Com isso o censo pode retratar um processo muito importante na sociologia das religiões no Brasil: o crescimento e multiplicação das denominações, das tradicionais às chamadas "new age". Isso fica muito claro quando se analisa o censo do ano 2000, onde estão disponíveis dados para dezenas de religiões diferentes, incluindo hinduísmo, budismo, taoísmo, racionalismo cristão, União do Vegetal, e neoxamânica. Na mesma linha, o censo 2010 enumerou nada menos do que 148 denominações religiosas diferentes, incluindo seis categorias de declaração múltipla.

Outra transformação importante diz respeito à forma como os dados são armazenados e disponibilizados. A partir de 1970, com a informatização do processamento, os dados censitários passaram a ser disponibilizados também na 
forma de microdados, como são chamados em sua forma de agregação mais granular. Assim os pesquisadores podem acessar não apenas as tabelas finais publicadas pelo IBGE mas também CDs contendo os microdados, que podem ser processados em programas de análise estatística tais como SPSS, SAS, R e outros. Assim, embora os dados publicados em papel ou na internet agreguem as categorias de forma a resumir o resultado das principais (em geral católicos, evangélicos, espirita e sem religião), com acesso aos microdados é possível ao pesquisador esmiuçar cada uma das centenas de religiões mencionadas, ao longo de pelo menos três décadas. Esses grupos podem ser desagregados em sua granulação máxima, ou agregadas em algumas categorias principais, dependendo do interesse do pesquisador. Além disso, as informações podem ser cruzadas por qualquer uma das variáveis disponíveis nos censos.

Resta lembrar que entre as categorias religiosas pesquisadas pelos censos encontra-se ainda uma que tem um significado singular: a dos sem religião. Este é o grupo que, ao lado dos evangélicos, mais tem crescido entre nós. Embora não se trate de uma religião, ela fornece uma métrica importante para dimensionar o processo de secularização por que tem passado a sociedade brasileira nas últimas décadas. O significado exato do que os entrevistados querem dizer quando se dizem "sem religião", é claro, é questão que deve ser discutida. Na literatura mais recente entende-se a resposta como sinônimo de pessoas sem vínculo com religiões institucionalizadas. Pois são exatamente as religiões institucionalizadas as que trazem implicações sociológicas mais importantes.

Este enorme manancial de dados sobre a religião dos brasileiros (e também sobre os brasileiros sem religião) constitui-se em um fantástico banco de dados em estado bruto sobre transformação religiosa em um país em processo de modernização, urbanização e industrialização, sem falar no massivo crescimento dos meios de comunicação, primeiro a TV, e mais recentemente a internet. Este enorme manancial continua desafiando a imaginação sociológica dos pesquisadores. Poucos países no mundo dispõem de um tesouro assim. Em termos de dados demográficos sobre religiões, o Brasil é uma espécie de paraíso. 